\title{
Towards an Identification of Provisos for the Implementation of Plurilingualism in Higher Education
}

\author{
María Del Carmen Méndez García \\ Universidad de Jaén \\ Sonia Casal Madinabeitia \\ Universidad Pablo de Olavide, Sevilla
}

Received: $18^{\text {th }}$ September $2017 /$ Accepted: $7^{\text {th }}$ February 2018

ISSN: 1697-7467

\begin{abstract}
The ongoing internationalization of Spanish universities has led to the introduction of ICLHE (Integration of Content and Language in Higher Education), where the aim is not only learning about a given academic subject but also developing linguistic competency in a foreign language. Some factors, such as lecturers' mastery of the language of instruction or effective teaching skills, have proved to have a clear impact on ICLHE. However, the literature reviewed reports a lack of research on clear specifications for an effective implementation of plurilingualism in higher education. This article aims at closing that gap, providing a number of provisos that may help universities to take linguistic, academic and political decisions towards a quality implementation of ICLHE. As a method to this general aim, requisites that plurilingualism demands at higher education have been analysed and categorised into four different groups: conditions, programme structure, lecturers' and students' skills, and methodological considerations. Findings of the article are illustrated by means of a final summary table that highlights categories and subcategories to be taken into consideration for ICLHE to be effective.
\end{abstract}

Keywords: plurilingualism, ICLHE, linguistic competency, provisos.

\section{Identificación de Estipulaciones Clave para la Implantación del Plurilingüismo en la Educación Superior}

RESUMEN: La progresiva internacionalización de las universidades españolas en aras de una mayor competitividad ha favorecido la introducción del enfoque ICLHE (Integración de Contenido y Lengua en la Educación Superior), donde se aúna el aprendizaje de una materia concreta con el desarrollo de la competencia en comunicación lingüística en una lengua extranjera. Las investigaciones previas a este estudio se han centrado en factores que tienen un claro efecto en la puesta en marcha de ICLHE, como el nivel de la lengua utilizada en el aula por los docentes o el uso de estrategias de enseñanza efectivas. Sin embargo, prácticamente no existen investigaciones que determinen el conjunto de especificaciones o factores que ayudan a llevar a cabo una puesta en marcha efectiva del plurilingüismo en la educación superior. Este artículo contribuye a cubrir ese vacío de información, examinando los principales parámetros que contribuyen a llevar a cabo un enfoque ICLHE de calidad y que han sido clasificados en cuatro grandes bloques: condiciones, estructura de los programas, destrezas de docentes y estudiantes, y consideraciones metodológicas. Los resultados del artículo se presentan en una tabla-resumen que especifica las categorías y subcategorías con las estipulaciones clave para guiar la implantación de titulaciones o itinerarios plurilingües en la educación superior.

Palabras clave: plurilingüismo, ICLHE, competencia en comunicación lingüística, condiciones / estipulaciones. 


\section{INTRODUCTION}

The effort Spanish universities are making to promote internationalization, from courses oriented to developing written and spoken communication to offering content subjects in an L2, is part of a European effort, where there has been an increase of $340 \%$ in programmes in English from 2002 to 2007 (Doiz et al., 2013). Content subjects taught in an L2 at university follow, in many cases, an ICLHE (Integration of Content and Language in Higher Education) approach, which stems from CLIL (Content and Language Integrated Learning) at primary and secondary levels, a markedly European phenomenon. As Pérez Cañado observed (2012: 318): 'CLIL is considered 'the European label for bilingual education' (Lorenzo, 2007: 28), as it is deeply rooted in the linguistic needs of the EU (Muñoz, 2007) and thus strongly European-oriented (Wolff, 2005)."

The rationale behind CLIL / ICLHE is that any subject may be taught through an L2. The objective of CLIL/ICLHE is dual: learning an L2 and learning content. This is reached through interactions between the oral, written and audio-visual material provided in the L2 and the participants in the teaching/learning process (Pavón and Rubio, 2010). The language component is secondary to the content and does not follow a strict order of functions, structures or vocabulary, but is rather one of the results to be achieved (Arnold, 2010).

CLIL / ICLHE is enclosed within the umbrella term coined by the Council of Europe "Languages of School Education" (LE), which comprehends three main areas:

a) "Language as a subject" (LS) in itself, traditionally related to the teaching of the first, second and foreign languages (FL), including classical languages;

b) "Language across the curriculum" (LAC), the language(s) employed as a means of instruction in other subjects;

c) "Language curriculum" (LC), the overarching language curriculum that comprises all the languages at students' disposal during their schooling, a variety of languages as a subject (first, second and/or foreign) and across the curriculum (Martyniuk, 2008).

As can be observed from the definitions above, CLIL / ICLHE are closely intertwined with LAC, embrace LS, and have a profound effect on LC. This intertwining of concepts has effects on CLIL / ICLHE's implementation, which can lead up to 3,000 possibilities bearing in mind content, language and organisation structures (Lorenzo, 2007).

While some research observing CLIL at primary and secondary levels indicates that the content addressed may be negatively affected (e.g. Bonnet 2012; Costa and D'Angelo 2011), other studies assert that the subject content is not only unaffected, but that learning through an additional language enhances learners' linguistic competency in the vehicular language(s), boosts learners' self-confidence and facilitates the development of a positive attitude towards the L2 (Aguilar \& Muñoz, 2014). Linguistic competences that seem to particularly benefit from CLIL tuition are receptive tasks, oral comprehension and production skills, vocabulary acquisition and use, lexical richness (chiefly specialised vocabulary), lexical transfer and written production. Contrarily, morphosyntax, pronunciation/accent, informal and non-technical language, and sentence-level writing do not seem to be heightened through CLIL (Aguilar \& Muñoz, 2014). 
Although little is known about ICLHE, lecturers' mastery of the language of instruction and effective lecturing skills prove to be paramount. Lecturers have been reported to display a possibly deficient ICLHE language competency - a less expressive, redundant and clear use of the language, less emphasis on necessary elements like reiteration and repetition of ideas and concepts, or reduced metadiscursive devices and stylistic lecturing variety. Likewise, there is some evidence that students face comprehension difficulties due to lecturers' inadequate pronunciation and use of unfamiliar vocabulary, which seems to induce a more superficial understanding of content. Furthermore, research shows that the lack of academic skills deployed in the mother tongue (L1) is similarly reflected in the ICLHE language (Aguilar \& Muñoz, 2014).

In light of these considerations, a wide array of factors seems to be crucial in the implementation of ICLHE. While research has been carried out for quality indicators in English Language Teaching at secondary education (Hughes, 2007), the literature review regarding ICLHE shows a lack of research that would ideally shed light on the linguistic, academic and political decisions to be taken at tertiary level (Fernández-Costales \& GonzálezRiaño, 2015). It is our aim to suggest some specifications that could lead to a common language policy in Spanish universities in the future, an issue which has recently been addressed by the Spanish CRUE (Conferencia de Rectores de las Universidades Españolas) (Bazo Martínez, González Álvarez, Centellas Rodrigo, Dafouz Milne, Fernández Costales \& Pavón, 2017). These specifications will be analysed in the next sections organized into to the following categories: conditions, programme structure, lecturers and students, and methodological considerations.

\section{Conditions}

The implementation of ICLHE is contingent on conditions that Mellion (2008) encapsulates in four dimensions. First, the socio-political dimension greatly determines the feasibility of ICLHE tuition as it rests on the stance and the support of both government and society concerning the internationalization of education and the use of languages other than the official language(s) of the country as means of instruction; additionally, the location of the institution (for instance, its proximity to another country or area where a different language is spoken) may influence the selection of the ICLHE language.

Second, the strategies put into practice by the university's board and personnel, making decisions and developing policies on international education, reveal their attitudes and support for an international orientation, which needs to be evident to the educational community through, for example, ICLHE pilot programmes, help from the international office, or acknowledgement of the official status of the programme. Third, funding for designing international curricula is pivotal for material development (translations of course descriptions, study guides and exam regulations) and staff stability, recruitment and training (hiring additional teaching staff or personnel for the international office, and training in the ICLHE language, including the fee for registering for exams). Fourth, organizational aspects such as publication of guidelines for recruiting international students, processing applications, providing overseas students with practical information about, for example, how to obtain or extend a visa, offering them accommodation or favouring effective and smooth communication are essential. 
Further requirements include the need to ensure collaboration among all stakeholders involved, the necessity to guarantee the continuity of the programme, both at an institutional and personal level, at all the stages of the process - from planning training programmes to administration (Mellion, 2008) and the establishment of a follow-up programme or protocol (Aguilar \& Muñoz, 2014).

In Spain, some decisions at autonomous government level have helped towards the consolidation of ICLHE. This is the case of universities in the Canary Islands, where the autonomous government has established that 12 credits in new degrees (5\%) be taught in a language of the European Union other than Spanish, English preferably. In a similar vein, Catalonian universities have invested 32 million euros in the accreditation of a B2 level in English for their graduates (Halbach et al., 2013).

\section{Programme structure}

Prior to the introduction of ICLHE, it is paramount to work towards an acknowledgment of the official status of the ICLHE programme through a degree of verification. This may be the case when ICLHE intends to be implemented in a new degree, or else, when there is a necessity to issue a Diploma Supplement if ICLHE is to be incorporated into an existing degree.

A highly important decision, though not exclusively for organizational, teaching and recruiting purposes, is the ICLHE model to be implemented. Toledo, Rubio \& Hermosín (2012) depict three models present in Spanish universities: 1) content subjects taught in the FL with a progressive increase in the number of credits; 2) choosing between following subjects in Spanish or in the FL; 3) agreements with foreign universities to enrol in content subjects abroad.

It follows that institutions need to specify whether the tuition they offer entails a full or a partial integration of the ICLHE language because teaching all the courses in the FL substantially differs from carrying out some of them through it (Karabinar, 2008). Full integration models are based on the assumption that all participants in the process master the FL and can pursue content courses in it. In this environment, the FL seems to constitute a "replacement language" (Alexander, 2008).

As for partial integration models, the L1 plays a relevant role; Karabinar (2008: 62) upholds that it promotes higher self-concepts in content and "is an important tool for learning the content since native language-medium courses are a better predictor for content knowledge when the students are provided with both native and foreign language-medium courses." In this model of ICLHE, the alternation of languages or code-switching, including the learners' L1, is primal. Since a specialised and competent use of a FL is required (Myers, 2008), research conducted on students' L1 seems to indicate that content knowledge is likely to be better predicted in native and FL-medium courses (Karabinar, 2008). Nevertheless, the feasibility of this assumption needs to be questioned as, among other aspects, code-switching does not seem to be operational in international contexts with students deploying a wide array of mother tongues and exhibiting from a varying to a lacking or even non-existent command of the local language. Partial integration courses may also deter international students who 
are not well versed in both languages from registering in them. A third paradigm consisting in using the FL as an "additional" language in some courses to expedite the transition of international students to courses offered in the local language may be implemented in order to compensate this lack of proficiency in the local language (Alexander, 2008).

The subjects taught in the FL likewise constitute essential aspects. In partial integration models, students may not select an optional subject if they perceive an apparent additional difficulty. In a similar vein, for compulsory subjects, if there are several groups, students may opt for the group that does not use the FL or even decide to change to this group if they perceive a higher difficulty; whereas, if there is a unique group, the necessities of students who wish to pursue their degree in their L1 may simply not be met. When there are several groups, lecturing staff who teach in their L1 may not be overtly cooperative if they believe that ICLHE affects content comprehension negatively (Fortanet, 2008). Therefore, the success of partial integration programmes may rest on both, the selection of courses taught through ICLHE, and the provision of alternative subjects, groups and/or itineraries for students who wish to pursue their degree in their L1. ICLHE tuition needs to be established progressively and course selection may be justified according to practical criteria (subjects whose materials are written in the FL or expected use of the FL in students' academic and/ or prospective professional contexts) (Fortanet, 2008).

Additionally, plurilingualism in higher education benefits from the internationalization of teaching experiences through, for instance, the promotion of teaching exchanges among lecturers from different contexts and the invitation extended to overseas lecturers to teach in the programme (Fortanet, 2008) either onsite or online through, for example, videoconferences or online sessions or workshops.

In contexts in which ICLHE is beginning to be incorporated or in contexts where it is not possible to implement it in all the years of the degree, the crux of the matter lies in temporalization. Lecturing staff seems to prefer tuition in the FL in the later years of undergraduate programmes, when students are more mature (Fortanet, 2008). This is why, in some institutions, ICLHE programmes have first been offered in postgraduate courses (Aguilar \& Muñoz, 2014). Nonetheless, the transition to plurilingual programme may be facilitated through "English for Specific Purposes" courses.

\section{LECTURERS AND STUDENTS}

Lecturers and students need to develop a series of competencies which Mellion (2008) assigns to three main categories: linguistic, didactic/learning and multicultural. Mellion (2008) emphasises that linguistic competency and confidence are intertwined since they involve mastery of the language of instruction, the display of positive attitudes towards it and the confidence to employ it as a vehicular language in the teaching and learning process. Furthermore, the nature of ICLHE makes the development of lecturers' didactic competencies and students' learning competencies in the FL inherent components of this paradigm in tertiary education. Similarly, the internationalization of higher education requires multicultural and intercultural competencies that favour intercultural dialogue and understanding among local and international lecturers and students. Hence, ICLHE needs to contemplate provisions to 
provide lecturing staff and students with opportunities to enhance their linguistic, didactic/ learning and multicultural competencies. As mentioned above, one possibility to enhance ICLHE participants' competencies and to acknowledge their efforts is to give them priority in exchange programmes (Fortanet, 2008).

Given the high relevance of linguistic competency, establishing a threshold level may be advisable or even become established as a requirement for students, since it seems that ICLHE may be more advantageous for learners with a below-intermediate level (for example, in the development of oral comprehension skills and grammar competency) (Aguilar and Muñoz, 2014). Likewise, institutions may wish to establish an optimal or minimum language proficiency level for lecturers in the FL to guarantee a beneficial effect on students' language proficiency since, if lecturers' language competency is limited, the improvement of students' linguistic competency may be threatened (Aguilar \& Muñoz, 2014).

A buddy or counselling system involving students from non-language degrees and $\mathrm{C} 1$ level students completing a degree in philological or translation areas, along with tailor-made language courses specially designed for students taking a specific ICLHE degree, could be activated in order to compensate for lacks in students' linguistic competency. However, quoting García's words: "Language is an important aspect, although by no means the most important, in considering the topic of bilingual education ... We focus here not on language per se but on the multiple discursive practices that constitute what we call languaging" (García 2009:40). This would suggest the importance of quality discursive exchanges between participants. In this sense, the enhancement of students' discovery and learning to learn skills, on the one hand, and presentation and academic writing skills, on the other, becomes particularly relevant (Zegers, 2008). Participation in ICLHE demands commitment and an active stance on the part of students, including the development of autonomy, cooperative learning and pro-active attitudes when it comes to selecting topics and tasks (Pavón\& Rubio, 2010).

As far as commitment of the teaching faculty is concerned, lecturers need to perceive smooth communication channels and feel the support of the educational community (Mellion, 2008); the commitment of all stakeholders is clearly the cornerstone of any educational initiative. Commitment is also heightened through explicit institutional support and incentives awarded to lecturing staff engaged in ICLHE, such as funding for material production and/or teaching load reductions (Fernández-Costales \& González-Riaño, 2015), awarding extra credits to Departments whose lecturers participate in plurilingual tuition, giving ICLHE lecturers priority when it comes to awarding teaching innovation projects, or giving them priority to receive guest teachers from other universities in the realm of the ICLHE programme (Fortanet, 2008).

Commitment needs to be accompanied with in-service staff preparation and training. Training in several possible fields, ideally both within and away from lecturers' institutions, has to be guaranteed in English for Academic Purposes (Fortanet, 2008), the pedagogical essentials of ICLHE (see next section), awareness of the basics of second language acquisition processes and intercultural communication - as lecturers need to cater for non-native speakers of the ICLHE and local languages (Klaassen, 2008; Mellion, 2008) - and C1 language courses - it is estimated that a minimum 4-6 week intensive course constitutes a requirement to improve language proficiency (Klaassen, 2008).

Indeed, language proficiency in the FL may become an entry requirement for new teaching personnel (Klaassen, 2008). Teaching faculty should be able to: 1) explain academic content 
in the FL with ease and confidence and be able to detect possible language difficulties; 2) design adapted and attractive material for students; 3) identify the language objectives of a given lesson plan (Arnold, 2010). Furthermore, the use of the FL by non-native teachers requires the university's agreement on language policy, the specification of guidelines for quality control of teaching in the FL and in-service training (Kling \& Hjulmand, 2008).

An additional key aspect is the support offered to ICLHE lecturers to plan their subjects through, for instance, the design of a common tool or template for the syllabus of all ICLHE subjects (Fortanet, 2008), professional revision of the materials prepared in the ICLHE language, the provision of internships to help lecturers translate their materials and/ or Powerpoint presentations (Aguilar and Muñoz, 2014), or favouring the interdepartmental and interdisciplinary collaboration of content and language lecturers from different areas (Friedenberg and Schneider, 2008; Mellion, 2008). Collaboration among teaching personnel is one of the most serious problems ICLHE models can face, since isolation and lack of coordination and communication tend to be the rule (Fernández-Costales \& González-Riaño, 2015).

\section{Methodological aspects}

The starting point for lecturers in order to make methodological decisions should probably be to assess their students' needs in detail, comparing students' proclaimed needs with lecturers' perceived estimate of these needs (Zegers, 2008). This analysis would lead to the identification and formulation of clear goals, expectations and (learning) outcomes of both theICLHE degrees in general and the particular subjects taught through ICLHE and assessment of the feasibility and/or desirability of alternating languages (FL and local language) or code-switching (Zegers, 2008).

Mastering the ICLHE language is not enough. It needs to be coupled with other elements such as exhibiting academic skills; i.e., skills to deliver oral presentations in the FL (Kling \& Hjulmand, 2008) and the knowledge of the components and language structures required to write a research report or paper (Lim, 2008). Consequently, lecturers not only need to master these elements, but also have to be able to offer guidelines to aid students' delivery of oral presentations and writing of research reports in the ICLHE language. Moreover, Klaassen (2008) singles out the need to encourage discussion and interaction in the classroom.

ICLHE has a profound effect on students' attention and rhythm of the class and ICLHE students' attention span seems to be significantly shorter than when the lesson is taught in the L1. Therefore, the use of a language distinct from students' L1 in ICLHE tuition calls for lecturers to incorporate compensation mechanisms related to the following fields:

a) Skills to manage different groupings in class and boost group work, cooperative work, project work (Bonnet, 2012) and a task-based approach (Poisel, 2012).

b) Classroom dynamics and abilities to increase students' input in the FL and encourage them to use the FL as much as possible.

c) Variety and diversity of materials and approaches.

d) Predominance of visual elements such as signposting, illustrations, diagrams (Klaassen, 2008) and mind maps. 
e) Non-verbal communication like gestures or keeping eye-contact.

f) Detailed explanation of concepts - including explanations of new terminology and explanations of terms or procedures in new ways - and the inclusion of clear and illustrative examples (Klaassen, 2008).

g) Emphasis on pronunciation elements affecting comprehension (like speed or placing emphasis), mastery of attention-pitch (Valcke \& Pavón, 2015) and suitable intonation patterns (Klaassen, 2008).

h) Specialised vocabulary, summary words (Klaassen, 2008) and glossaries.

i) Specialised discourse and grammar structures, notably phrases and sentence structures in the FL and, in particular, in connection with genres (argumentative, narrative, descriptive or expository) (Cendoya \& Di Bin, 2010).

j) Promotion of students' discovery skills and learning to learn skills.

k) Alternative assessment tools and criteria adapted to ICLHE teaching.

1) Emphasis on scaffolding language techniques to foster language use (such as modelling or contextualising) and to facilitate its understanding (like rephrasing, maximisation of redundancy, exemplifying, schema building, comparison, or use of synonyms and antonyms) (van de Pol, Volman \& Beishuizen, 2010; Walqui, 2006). Information and communication technologies (ICT) constitute a powerful resource to expedite linguistic scaffolding processes (Koenraa et al., 2008).

Designing ICLHE materials, though time-consuming and, therefore, expensive, is pivotal. For ICLHE contexts involving non-native speakers of the language, such as immigrants or international students, Friedenberg and Schneider (2008) put forward a "sheltered instruction" model in which language and content specialists collaborate, for example, in the simplification of the language structures or in the creation of simplified supplementary tasks that keep the intellectual integrity of the material. In heterogeneous groups with participants from diverse disciplines and areas a possibility is the selection of common general themes that allow students to carry out an analysis of the topic in question from their own disciplines: an example is immigration, an issue that medical students can address from a medical perspective whereas law students may look at the legal aspects of the phenomenon (Breeze, 2008).

The implementation of approaches that favour student reflection becomes a sine qua non in higher education. Reflection may be stimulated through portfolios submitted at the end of the term or semester accompanied by students' informed reports. Lecturers may orientate students by proposing prompts for a semi-guided informed and critical reflection on, for instance, the process, learning goals and methods employed to meet the goals. The Common European Framework of Reference for Languages (Council of Europe, 2001) may be employed as a benchmark (Haines \& Ashworth, 2008).

\section{Conclusions}

This article has aimed at suggesting provisos for the implementation of plurilingualism at tertiarylevel. Table 1 provides a summary of these divided into categories and subcategories. As extended research for this first approach to quality ICLHE implementation, it would be 
enriching to plan and execute empirical studies that would shed light on factors that need further consideration such as whether additional requirements need to be pondered, whether these specifications are imperative in all contexts of ICLHE in higher education, or whether their relevance varies across higher education settings.

Table 1. Overview of provisos for plurilingual education in higher education

\begin{tabular}{|c|c|}
\hline $\begin{array}{l}\text { CATEGORIES AND } \\
\text { SUBCATEGORIES }\end{array}$ & ITEMS \\
\hline \multicolumn{2}{|l|}{ Conditions } \\
\hline \multirow{3}{*}{$\begin{array}{l}\text { Socio-political } \\
\text { dimension }\end{array}$} & $\begin{array}{l}\text { - Stance taken by and support of the government concerning the internationaliza- } \\
\text { tion of education and the use of second/foreign languages as means of instruction. }\end{array}$ \\
\hline & $\begin{array}{l}\text { - Stance taken by and support of society concerning the internationalization of edu- } \\
\text { cation and the use of second/foreign languages as means of instruction. }\end{array}$ \\
\hline & - Location of the institution and its effect on the selection of the ICLHE language. \\
\hline \multirow{4}{*}{$\begin{array}{l}\text { Strategies em- } \\
\text { ployed }\end{array}$} & $\begin{array}{l}\text { - Attitudes towards and support of an international orientation (i.e., pilot pro- } \\
\text { grammes, help from the international office, or acknowledgement of the official } \\
\text { status of the programme) on the part of the university's board and decision-mak- } \\
\text { ers concerning policy in international education. }\end{array}$ \\
\hline & - Ensuring collaboration among all stakeholders involved. \\
\hline & $\begin{array}{l}\text { - Guaranteeing the continuity of the programme, both at an institutional and per- } \\
\text { sonal level, in all the stages of the process. }\end{array}$ \\
\hline & - Establishment of a follow-up programme or protocol. \\
\hline \multirow{2}{*}{ Funding } & $\begin{array}{l}\text { - Funding for material development (translations of course descriptions, study } \\
\text { guides and exam regulations). }\end{array}$ \\
\hline & $\begin{array}{l}\text { - Funding for staff stability, recruiting and training (hiring additional teaching staff } \\
\text { or personnel for the international office, and training in the ICLHE language). }\end{array}$ \\
\hline Organization & $\begin{array}{l}\text { - Guidelines for recruiting international students, processing applications, pro- } \\
\text { viding overseas students with information about, for example, how to obtain or } \\
\text { extend a visa, offering them accommodation, or favouring effective/smooth com- } \\
\text { munication. }\end{array}$ \\
\hline \multicolumn{2}{|c|}{ Programme Structure } \\
\hline $\begin{array}{c}\text { Official } \\
\text { acknowledgment }\end{array}$ & $\begin{array}{l}\text { - Acknowledgment of the official status of the ICLHE programme though a degree } \\
\text { verification or the issue of a Diploma Supplement. }\end{array}$ \\
\hline ICLHE model & $\begin{array}{l}\text { - Specification of the ICLHE model: a) full integration of the ICLHE language; b) } \\
\text { partial integration of the foreign language, c) use of the foreign language as an } \\
\text { "additional" language. }\end{array}$ \\
\hline
\end{tabular}




\begin{tabular}{|c|c|}
\hline \multirow{6}{*}{ Subjects } & $\begin{array}{l}\text { - For partial integration programmes, specification of the subjects, optional and/or } \\
\text { compulsory, taught in the foreign language. }\end{array}$ \\
\hline & $\begin{array}{l}\text { - For partial integration programmes, provision of alternative subjects, groups and/ } \\
\text { or itineraries for students who wish to pursue their degree in their mother tongue. }\end{array}$ \\
\hline & - For partial integration programmes, progressive establishment of the programme. \\
\hline & $\begin{array}{l}\text { - For partial integration programmes, selection of the courses taught through } \\
\text { ICLHE based on practical criteria (subjects whose materials are written in the FL } \\
\text { or expected use of the FL in students' academic and/or prospective professional } \\
\text { contexts). }\end{array}$ \\
\hline & $\begin{array}{l}\text { - Facilitating the transition to the ICLHE programme through, for instance, "En- } \\
\text { glish for Specific Purposes" courses. }\end{array}$ \\
\hline & $\begin{array}{l}\text { - Internationalization of teaching experiences in ICLHE programme/subjects } \\
\text { through, for instance, the promotion of teaching exchanges and the invitation ex- } \\
\text { tended to overseas lecturers to participate onsite or online (i.e. videoconferences } \\
\text { or online sessions or workshops). }\end{array}$ \\
\hline Temporalization & $\begin{array}{l}\text { - If ICLHE cannot be implemented in all the years of the degree, tuition in the FL } \\
\text { offered according to students' maturity (i.e. last years of undergraduate or post- } \\
\text { graduate programmes). }\end{array}$ \\
\hline \multicolumn{2}{|c|}{ LECTURERS AND STUDENTS } \\
\hline \multirow{6}{*}{ Competencies } & - Lecturers and students' linguistic competency in the language of instruction. \\
\hline & $\begin{array}{l}\text { - Institutional provisions to offer lecturing staff and students opportunities to en- } \\
\text { hance their linguistic competencies. }\end{array}$ \\
\hline & - Lecturers' didactic competencies / students' learning competencies in the FL. \\
\hline & $\begin{array}{l}\text { - Institutional provisions to offer lecturing staff and students opportunities to en- } \\
\text { hance their didactic/learning competencies. }\end{array}$ \\
\hline & - Lecturers and students' multicultural/intercultural competencies. \\
\hline & $\begin{array}{l}\text { - Institutional provisions to offer lecturing staff and students opportunities to en- } \\
\text { hance their multicultural/intercultural competencies. }\end{array}$ \\
\hline $\begin{array}{l}\text { Recognition / } \\
\text { incentive }\end{array}$ & - Lecturers and students' priority to take part in exchange programmes. \\
\hline \multirow{2}{*}{ Threshold levels } & - Establishment of an optimal/minimum language proficiency level for lecturers. \\
\hline & - Establishment of a threshold language proficiency level for students. \\
\hline \multicolumn{2}{|l|}{ Students } \\
\hline Commitment & - Commitment in the ICLHE programme and active attitude. \\
\hline Language training & $\begin{array}{l}\text { - Tailor-made language courses especially designed for students doing a specific } \\
\text { ICLHE degree. }\end{array}$ \\
\hline $\begin{array}{l}\text { Further linguistic } \\
\text { support }\end{array}$ & $\begin{array}{l}\text { - Buddy or counselling system involving students from non-language degrees and } \\
\text { C1 level students completing a degree in philological or translation areas. }\end{array}$ \\
\hline \multirow{5}{*}{ Skills } & - Enhancement of discovery and learning to learn skills. \\
\hline & - Enhancement of presentation skills. \\
\hline & - Enhancement of academic writing skills. \\
\hline & - Development of autonomy. \\
\hline & - Pro-active attitudes when it comes to selecting topics and tasks. \\
\hline
\end{tabular}




\begin{tabular}{|c|c|}
\hline \multicolumn{2}{|l|}{ LECTURERS } \\
\hline Commitment & - Commitment of the teaching faculty. \\
\hline $\begin{array}{l}\text { Relation with the } \\
\text { educational com- } \\
\text { munity }\end{array}$ & $\begin{array}{l}\text { - Smooth communication with and support of the educational community to the } \\
\text { lecturers. }\end{array}$ \\
\hline Recognition & $\begin{array}{l}\text { - Incentives awarded to lecturers involved in ICLHE (i.e. funding for material } \\
\text { production, allowable teaching load reduction, awarding extra credits to Depart- } \\
\text { ments whose lecturers participate in ICLHE, giving ICLHE lecturers priority in } \\
\text { the award of teaching innovation projects or giving them priority to receive guest } \\
\text { teachers from other/foreign universities). }\end{array}$ \\
\hline \multirow{6}{*}{ Training } & - Guaranteeing training, ideally within and away from lecturers' institution. \\
\hline & - Training in English for Academic Purposes. \\
\hline & - Training in the pedagogical essentials of ICLHE. \\
\hline & - Training in the basics of second language acquisition processes. \\
\hline & - Training in intercultural communication. \\
\hline & - C1 language courses in the ICLHE language. \\
\hline \multirow{4}{*}{$\begin{array}{l}\text { Support to plan } \\
\text { ICLHE subjects }\end{array}$} & - Availability of a common tool or template for the syllabus of all ICLHE subjects. \\
\hline & $\begin{array}{l}\text { - Professional translators' or translator centres' revision of the materials prepared } \\
\text { in the ICLHE language. }\end{array}$ \\
\hline & $\begin{array}{l}\text { - Provision of internships to help lecturers translate their materials and/or Power- } \\
\text { point presentations. }\end{array}$ \\
\hline & - Favouring the collaboration among lecturers from different disciplines. \\
\hline $\begin{array}{l}\text { Entry require- } \\
\text { ments }\end{array}$ & $\begin{array}{l}\text { - Language proficiency in the FL becomes an entry requirement for new teaching } \\
\text { personnel. }\end{array}$ \\
\hline \multirow{2}{*}{$\begin{array}{l}\text { Quality control of } \\
\text { teaching }\end{array}$} & $\begin{array}{l}\text { - University's agreement on a policy and specification of guidelines for quality } \\
\text { control of teaching in the FL. }\end{array}$ \\
\hline & $\begin{array}{l}\text { - University's agreement on a policy and specification of guidelines for quality } \\
\text { control of in-service training. }\end{array}$ \\
\hline \multicolumn{2}{|c|}{ METHOdOLOGiCAL CONSIDERATIONS } \\
\hline \multirow{3}{*}{ Needs analysis } & - Detailed assessment of students'needs. \\
\hline & $\begin{array}{l}\text { - Comparison between students' proclaimed needs and lecturers' perceived esti- } \\
\text { mate of their students' needs. }\end{array}$ \\
\hline & $\begin{array}{l}\text { - Formulation of clear goals, expectations and outcomes of both the ICLHE de- } \\
\text { grees in general and the particular subjects taught through ICLHE. }\end{array}$ \\
\hline Code-switching & $\begin{array}{l}\text { - Assessment of the feasibility and/or desirability of alternating languages (FL and } \\
\text { local language) or code-switching. }\end{array}$ \\
\hline
\end{tabular}




\begin{tabular}{|c|c|}
\hline \multirow{18}{*}{$\begin{array}{l}\text { Compensation } \\
\text { mechanisms and } \\
\text { lecturers' skills }\end{array}$} & $\begin{array}{l}\text { - Skills to manage different groupings in class and boost group work, cooperative } \\
\text { work, project work and a task-based approach. }\end{array}$ \\
\hline & $\begin{array}{l}\text { - Liveliness and abilities to increase students' input in the FL and encourage them } \\
\text { to use the FL as much as possible. }\end{array}$ \\
\hline & - Variety and diversity of materials and approaches. \\
\hline & - Non-verbal communication (gestures or eye-contact). \\
\hline & $\begin{array}{l}\text { - Predominance of visual elements such as signposting, illustrations, diagrams and } \\
\text { mind maps. }\end{array}$ \\
\hline & $\begin{array}{l}\text { - Detailed explanation of concepts and explanations of things in new ways accom- } \\
\text { panied by clear and illustrative examples. }\end{array}$ \\
\hline & $\begin{array}{l}\text { - Emphasis on pronunciation elements affecting comprehension (speed or placing } \\
\text { emphasis), mastery of attention-pitch and suitable intonation patterns. }\end{array}$ \\
\hline & - Specialised vocabulary, summary words and glossaries. \\
\hline & $\begin{array}{l}\text { - Specialised discourse and grammar structures (phrases and sentence structures) in } \\
\text { the FL and, in particular, in connection with the genres (argumentative, narrative, } \\
\text { descriptive or expository). }\end{array}$ \\
\hline & - Promotion of students' discovery skills and learning to learn skills. \\
\hline & - Alternative assessment tools and criteria adapted to ICLHE teaching. \\
\hline & $\begin{array}{l}\text { - Emphasis on scaffolding content techniques to facilitate understanding (rephras- } \\
\text { ing, maximising redundancy, exemplifying, comparing, or using synonyms and } \\
\text { antonyms). }\end{array}$ \\
\hline & $\begin{array}{l}\text { - Emphasis on scaffolding language techniques to foment language use (i.e. mod- } \\
\text { elling or contextualizing). }\end{array}$ \\
\hline & - Use of $I C T$ to facilitate linguistic scaffolding. \\
\hline & $\begin{array}{l}\text { - Exhibiting academic skills: skills to deliver oral presentations and knowledge of } \\
\text { the components and language structures required to write a research report or } \\
\text { paper in the FL. }\end{array}$ \\
\hline & $\begin{array}{l}\text { - Offering guidelines to aid students deliver oral presentations and write a research } \\
\text { report in the ICLHE language. }\end{array}$ \\
\hline & - Dexterity to encourage discussion and interaction in the classroom. \\
\hline & $\begin{array}{l}\text { - Ability to stimulate students reflection on, for instance, the learning process, } \\
\text { learning goals and methods employed to meet the goals. }\end{array}$ \\
\hline \multirow{3}{*}{$\begin{array}{l}\text { Materials design } \\
\text { and resources }\end{array}$} & $\begin{array}{l}\text { - In ICLHE contexts involving non-native speakers of the language, collaboration } \\
\text { among language and content specialists ("sheltered instruction" model) in the } \\
\text { simplification of the language structures or in the creation of simplified supple- } \\
\text { mentary tasks that keep the intellectual integrity of the material. }\end{array}$ \\
\hline & $\begin{array}{l}\text { - In heterogeneous groups with participants from diverse disciplines, selection of } \\
\text { common general themes that allow students to carry out an analysis of the topic in } \\
\text { question from their own disciplines. }\end{array}$ \\
\hline & $\begin{array}{l}\text { - Use of students' portfolios accompanied by an informed report on the portfolios } \\
\text { to promote informed and critical reflection }\end{array}$ \\
\hline
\end{tabular}


Source: Based on Aguilar \& Muñoz, 2014; Alexander, 2008; Bonnet, 2012; Breeze, 2008; Cendoya \& Di Bin; Fernández-Costales \& González-Riaño, 2015; Fortanet, 2008; Friedenberg \& Schneider, 2008; Haines \& Ashworth, 2008; Karabinar, 2008; Klaassen, 2008; Kling \& Hjulmand, 2008; Koenraa et al., 2008; Lim, 2008; Martyniuk, 2008; Mellion, 2008; Myers, 2008; Pavón \& Rubio, 2010; Poisel, 2012; Valcke \& Pavón, 2015; van de Pol, Volman \& Beishuizen, 2010; Zegers, 2008.

\section{REFERENCES}

Aguilar, M. \& Muñoz, M. (2014). The effect of proficiency on CLIL benefits in engineering students in Spain. International Journal of Applied Linguistics, 24(1), 1-18.

Alexander, R.J. (2008). International programmes in the German-speaking world and Englishization: A critical analysis, in R. Wilkinson and V. Zegers (Eds.) Realizing Content and Language Integration in Higher Education (pp. 77-95). Maastricht: Maastricht University.

Arnold, W. (2010). Where is CLIL taking us? Pulso, 33, 227-233.

Bazo Martínez, P., González Álvarez, D., Centellas Rodrigo, A., Dafouz Milne, E., Fernández Costales, A., \& Pavón Vázquez, V. (2017) Política Lingüistica para la Internacionalización del Sistema Universitario Español. Available from: http://www.crue.org/Documentos\%20 compartidos/Sectoriales/Internacionalizaci\%C3\%B3n\%20y\%20Coorperaci\%C3\%B3n/ Politica\%20linguistica\%20Internacionalizacion\%20SUE.pdf, accessed 5 February, 2018.

Bonnet, A. (2012). Towards an evidence base for CLIL: How to integrate qualitative and quantitative as well as process, product and participant perspectives in CLIL research. International CLIL Research Journal, 1(4), 66-78.

Breeze, R. (2008). Academic writing in the Spanish university context: changing the language, changing the paradigm, in R. Wilkinson \& V. Zegers (Eds.), Realizing Content and Language Integration in Higher Education (pp. 110-118). Maastricht: Maastricht University.

Cendoya, A. \& Di Bin, M. (2010). A CLIL experience based on the use of tasks and different genre types. Latin American Journal of Content and Language Integrated Learning, 3(1), 11-17.

Costa, F. \& D'Angelo, L. (2011.). CLIL: A suit for all seasons. Latin American Journal of Content and Language Integrated Learning, 4(1), 1-13.

Council of Europe. (2001). Common European Framework of Reference for Languages. Cambridge: Cambridge University Press.

Doiz, A., Lasagabaster, D., \& Sierra, J.M. (2013). What does 'international university' mean at a European bilingual university? The role of languages and culture. Language Awareness, 23(2), 172-186.

Fernández-Costales, A. \& González-Riaño, X.A. (2015). Teacher satisfaction concerning the implementation of bilingual programmes in a Spanish university. Porta Linguarum, 23, 93-108.

Fortanet, I. (2008). Questions for debate in English medium lecturing in Spain, in R. Wilkinson and V. Zegers (Eds.), Realizing Content and Language Integration in Higher Education (pp. 21-31). Maastricht: Maastricht University.

Friedenberg, J.E. \& Schneider, M. (2008). An experiment in sheltered sociology at the university level, in R. Wilkinson \& V. Zegers (Eds.), Realizing Content and Language Integration in Higher Education (pp. 155-168). Maastricht: Maastricht University.

García, O. (2009). Bilingual Education in the 21st Century. A Global Perspective. Chichester, UK: Wiley-Blackwell.

Haines, K. \& Ashworth, A. (2008). A reflective approach to HE language provision: integrating context and language through semi-structure reflection, in R. Wilkinson \& V. Zegers (Eds.), Realizing Content and Language Integration in Higher Education (pp. 201-212). Maastricht: Maastricht University.

Halbach, A., Lázaro Lafuente, A. \& Pérez Guerra, J. (2013). La lengua inglesa en la nueva universidad española delEEES. Revista de Educación, 362, 105-132. 
Hughes, S. (2007). The identification of quality indicators in English Language Teaching: A study in compulsory and non-compulsory secondary level language education in the province of Granada. Doctoral Dissertation. Granada: Editorial Universidad de Granada. Available from: https://www.researchgate.net/publication/284551772_The_identification_of_quality_indicators_in_English_language_teaching, accessed 11 April, 2018.

Karabinar, S. (2008). Integrating language and content: Two models and their effects on the learners' academic self-concept, in R. Wilkinson \& V. Zegers (Eds.), Realizing Content and Language Integration in Higher Education (pp. 53-63). Maastricht: Maastricht University.

Klaassen, R. (2008). Preparing lecturers for English-medium instruction, in R. Wilkinson \& V. Zegers (Eds.), Realizing Content and Language Integration in Higher Education (pp. 3242). Maastricht: Maastricht University,

Kling, J. \& Hjulmand L.L. (2008). PLATE -Project in Language Assessment for Teaching in English, in R. Wilkinson \& V. Zegers (Eds.), Realizing Content and Language Integration in Higher Education(pp. 191-200). Maastricht: Maastricht University.

Koenraa, T., Hajer, M., Hootsen, G., \& van der Werf, R. (2008). Towards a linguistically scaffolded curriculum. How can technology help?, in R. Wilkinson \& V. Zegers (Eds.), Realizing Content and Language Integration in Higher Education (pp. 64-73). Maastricht: Maastricht University.

Lim, J.M.H. (2008). Analyzing recommendations for future research: An investigation into a hybrid sub-genre, in R. Wilkinson \& V. Zegers (Eds.), Realizing Content and Language Integration in Higher Education (pp. 131-154). Maastricht: Maastricht University.

Lorenzo, F. (2007). An analytical framework of language integration in L2 content-based courses: The European Dimension. Language and Education, 21(6), 502-514.

Martyniuk, W. (2008). CLIL - at the core of plurilingual education?, in R. Wilkinson \& V. Zegers (Eds.), Realizing Content and Language Integration in Higher Education (pp. 13-18). Maastricht: Maastricht University.

Mellion, M.J. (2008). The challenge of changing tongues in business university education, in R. Wilkinson \& V. Zegers (Eds.), Realizing Content and Language Integration in Higher Education (pp. 212-227). Maastricht: Maastricht University.

Myers, M.J. (2008). Code switching in content learning, in R. Wilkinson \& V. Zegers (Eds.), Realizing Content and Language Integration in Higher Education (pp. 43-52). Maastricht: Maastricht University.

Pavón Vázquez, V. \& Rubio, F.D. (2010). Teachers' concerns and uncertainties about the introduction of CLIL programmes. Porta Linguarum, 14, 45-58.

Pérez-Cañado, M.L. (2012). CLIL research in Europe: past, present, and future. International Journal of Bilingual Education and Bilingualism, 15(3), 315-341.

Poisel, E. (2012). Competence development through task-based learning, in D. Marsh \& O. Meyer (Eds.), Quality Interfaces: Examining Evidence \& Exploring Solutions in CLIL (pp. 251263). Eichstätt: Eichstätt Academic Press.

Toledo, I., Rubio, F.D. \& Hermosín, M. (2012). Creencias, rendimiento académico y actitudes de alumnos universitarios principiantes en un programa plurilingüe. Porta Linguarum, 18, 213-229.

Valcke, J. \& Pavón, V. (2015). Transmitting complex academic information effectively: A comparative study on the use of pronunciation strategies for highlighting information in university lectures, in R. Wilkinson and M.L. Walsh (Eds.), Integrating Content and Language in Higher Education: From Theory to Practice (pp. 323-341). Frankfurt-am-Main: Peter Lang.

Van de Pol, J., Volman, M., \& Beishuizen, J. (2010). Scaffolding in teacher-student interaction: A decade of research. Educational Psychology Review, 22(3), 271-296.

Walqui, A. (2006). Scaffolding instruction for English language learners: a conceptual framework. International Journal of Bilingual Education and Bilingualism, 9(2), 159-180.

Zegers, V. (2008). When European Studies met English: A practitioner's view on content and language integrated learning, in R. Wilkinson \& V. Zegers (Eds.), Realizing Content and Language Integration in Higher Education (pp. 228-236). Maastricht: Maastricht University. 